аспирант кафедры управления

в международном бизнесе и индустрии туризма

Государственного университета управления

\section{ЭКОНОМИЧЕСКОЕ СООБЩЕСТВО АСЕАН И ТРУДНОСТИ В ПРОЦЕССЕ РАЗВИТИЯ ТУРИЗМА}

\section{Аннотация:}

Для углубления сотрудничества между странами - членами Ассоциации государств Юго-Восточной Азии (АCEAH) как в сфере туризма, так и в других областях в коние 2015 г. было создано экономическое сообщество АEC. Это событие имеет большое значение для развития туризма в государствах региона. В статье выявлены и проанализированы трудности, которым должны противостоять участники АСЕАН для достижения целей при совершенствовании системы гостиничного и туристского бизнеса.

Ключевые слова:

гостиничный и туристский бизнес, АСEAН, уровень развития, терроризм, массовый туризм, "утечка мозгов".
PhD student, Department for Management in International Business and Tourism Industry, State University of Management

\section{ASEAN ECONOMIC COMMUNITY AND CHALLENGES IN TOURISM DEVELOPMENT PROCESS}

To deepen cooperation between member countries of the Association of Southeast Asian Nations (ASEAN) both in tourism service and other fields, the ASEAN Economic Community (AEC) was established at the end of 2015. This event has a great meaning for tourism development of the ASEAN. The article identifies and analyzes the challenges, which ASEAN member countries have to resist to achieve the goals during the improvement of the hotel and tourism business system.

Keywords: hotel and tourism business, ASEAN, development level, terrorism, mass tourism, brain drain.

Создание экономического сообщества в конце 2015 г. определило новую стадию сотрудничества стран-членов АСЕАН. Расширение этих отношений открывает возможности для развития гостиничного и туристского бизнеса (ГТБ). При этом выявление и анализ трудностей, неизбежно возникающих на данном пути, представляют собой актуальную задачу. По нашему мнению, после формирования общего рынка для раскрытия потенциала индустрии туризма необходимо обратить внимание на значимые проблемы государств - участников АСЕАН в рассматриваемой сорере.

1. Между странами - членами АСЕАН существуют различия не только в уровне развития экономики, включая сферу ГТБ, но и в регулировании экономики, политики и общественных отношений. Они могут послужить препятствиями для сотрудничества и совместного развития туризма всего региона.

Большая разница в показателях ВВП, валового национального дохода на душу населения и развития информационно-коммуникационных технологий (ИКТ) стран - членов АСЕАН обусловливает снижение конкурентоспособности региона в привлечении инвестиционных потоков (рисунок 1). Для государств с низким уровнем благосостояния это представляет большую проблему при совершенствовании инфраструктуры, повышении квалификации кадров и качества обслуживания в сфере туризма и т. д. Кроме того, разница в уровне развития стран - участниц АЕС затрудняет разработку общей политики в области туризма для обеспечения совместных интересов, а также приводит к противоречиям при реализации заключенных соглашений и снижению эффективности сотрудничества.

Объем инвестиций в экономику Сингапура занимает около половины вложений в регион (рисунок 2). Индонезия, Таиланд, Малайзия и Вьетнам получают немалые доли, а остальные члены привлекают малый объем инвестиционных потоков. Это также становится препятствием для реализации стратегий развития ГТБ.

Различия в степени конкурентоспособности в секторе путешествий и туризма стран - членов АCEAН не менее значимы (рисунок 3). Этот индекс выше у государств с развитым туризмом (Сингапура, Малайзии, Таиланда, Индонезии). Средняя оценка каждого элемента индекса конкурентоспособности в секторе путешествий и туризма (ИКПТ) у развитых и развивающихся стран региона также отражает их заметные различия (рисунок 4).

Низкая конкурентоспособность в секторе путешествий и туризма приводит к снижению объемов иностранных инвестиций, что замедляет темпы развития рассматриваемой сферы. В свою очередь государства с развитым туризмом интенсивно улучшают инфраструктуру, повышают качество обслуживания и квалификацию персонала в данной сфере, непрерывно укрепляют свои позиции на рынке благодаря большему притоку инвестиционных средств. Остальные участники АСЕАН развивают ГТБ на фоне сложных актуальных проблем, таких как низкий уровень жизни населения, неподходящая инфраструктура, невысокое качество образования и т. д. 


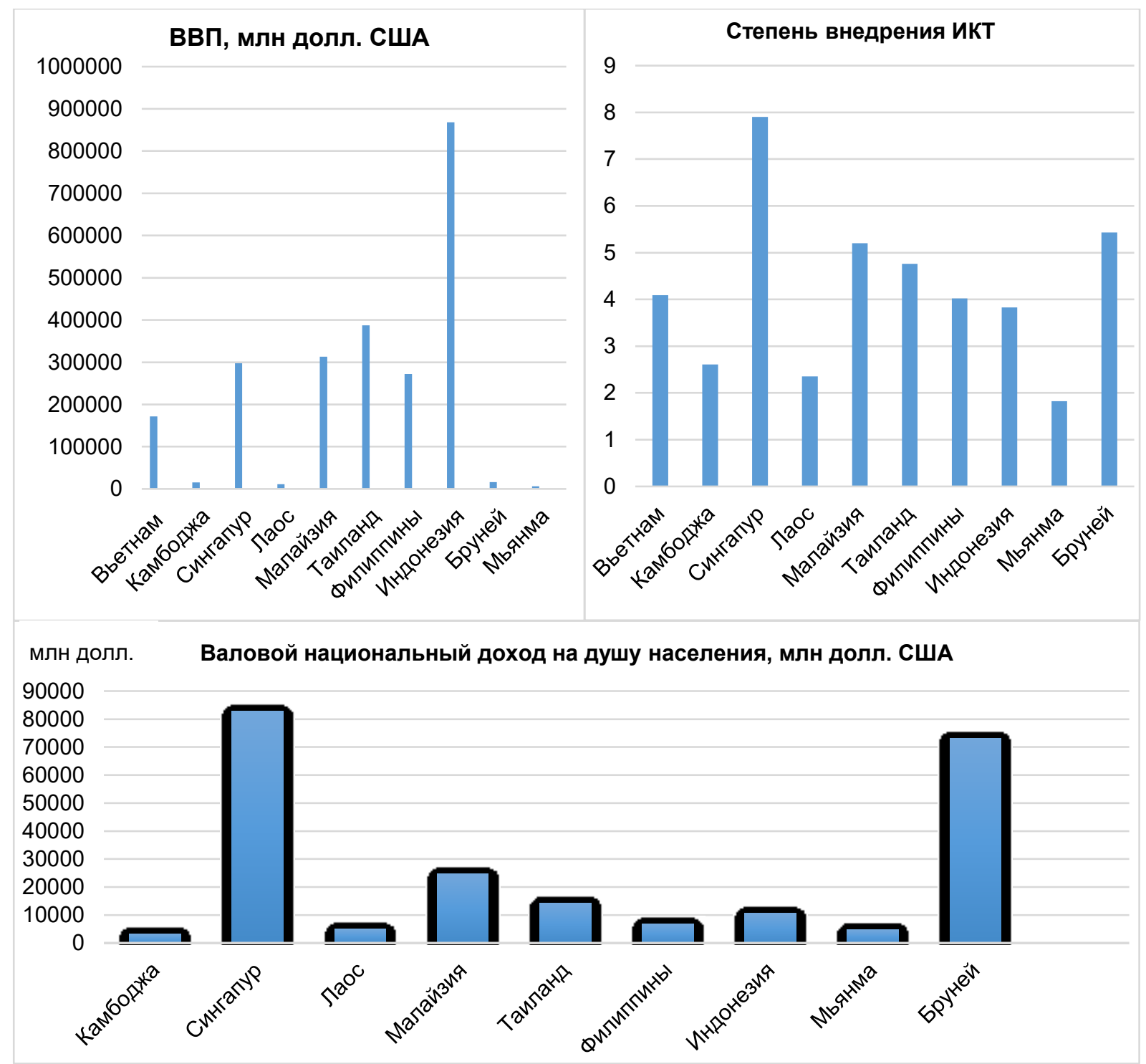

Рисунок 1 - Различия в уровне развития стран - членов АСЕАН [1]

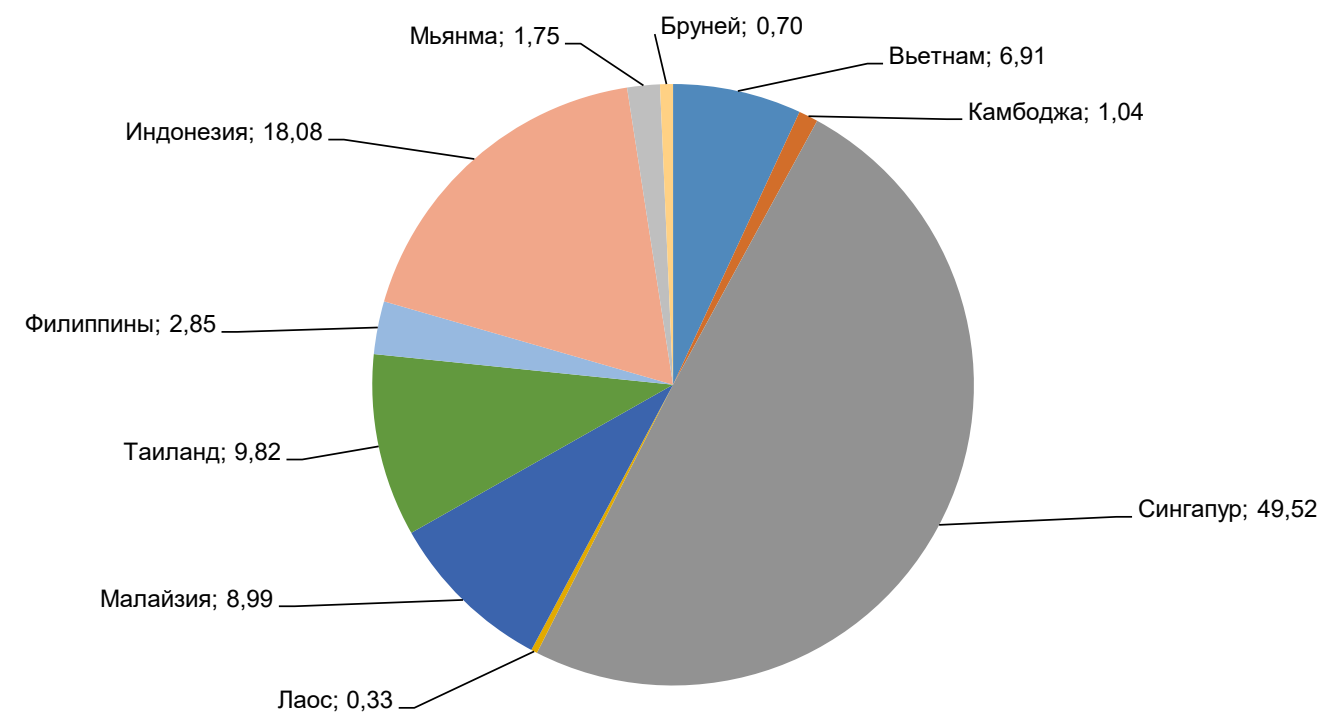

Рисунок 2 - Доля инвестиции в регион, \% [2] 


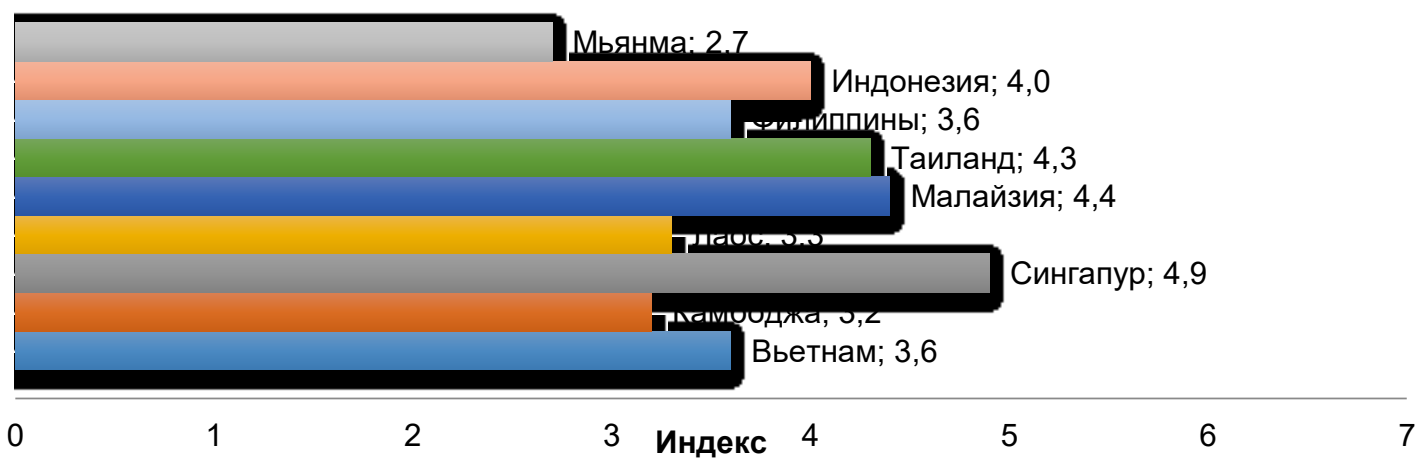

Рисунок 3 - Индекс конкурентоспособности в секторе путешествий и туризма [3]

a

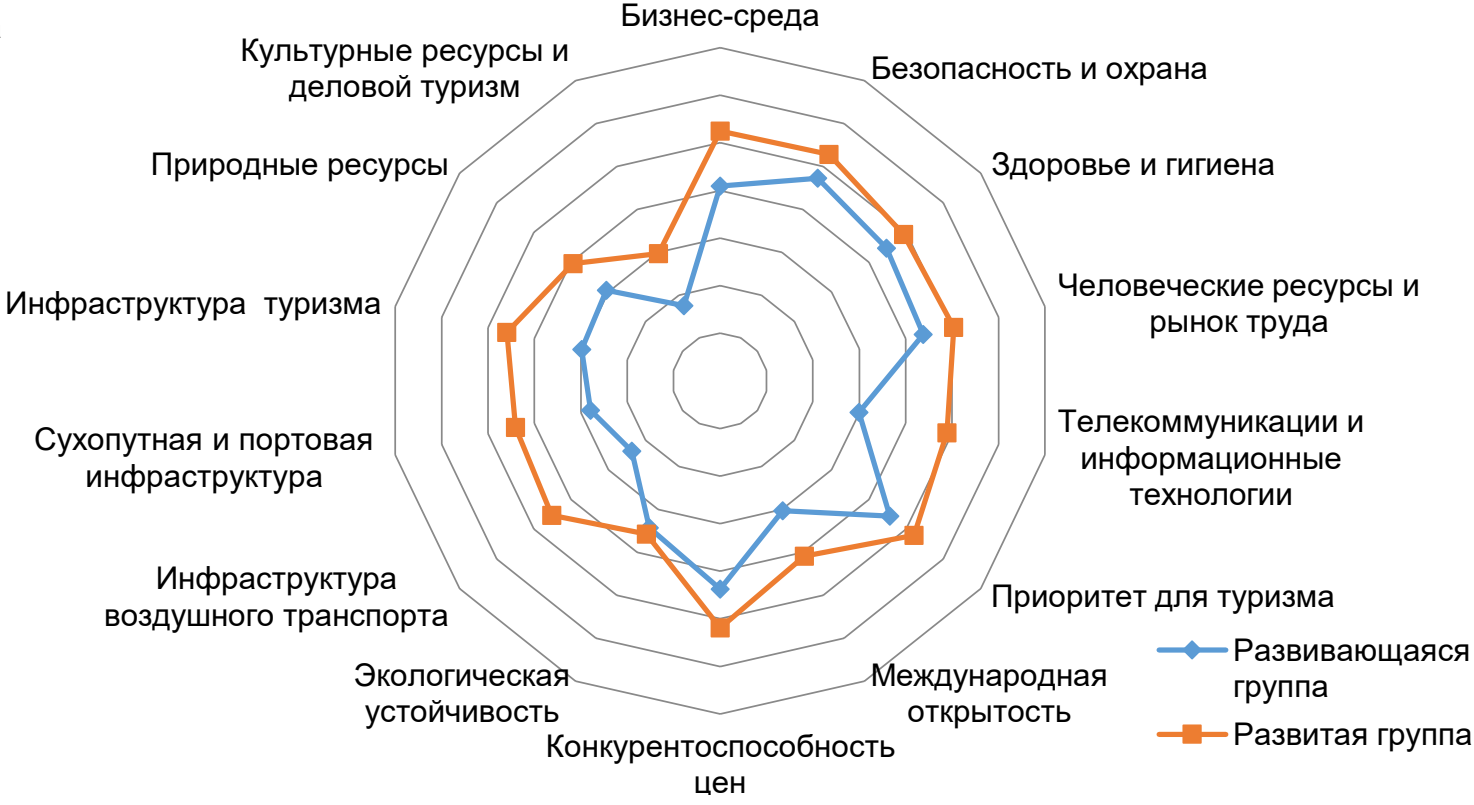

б

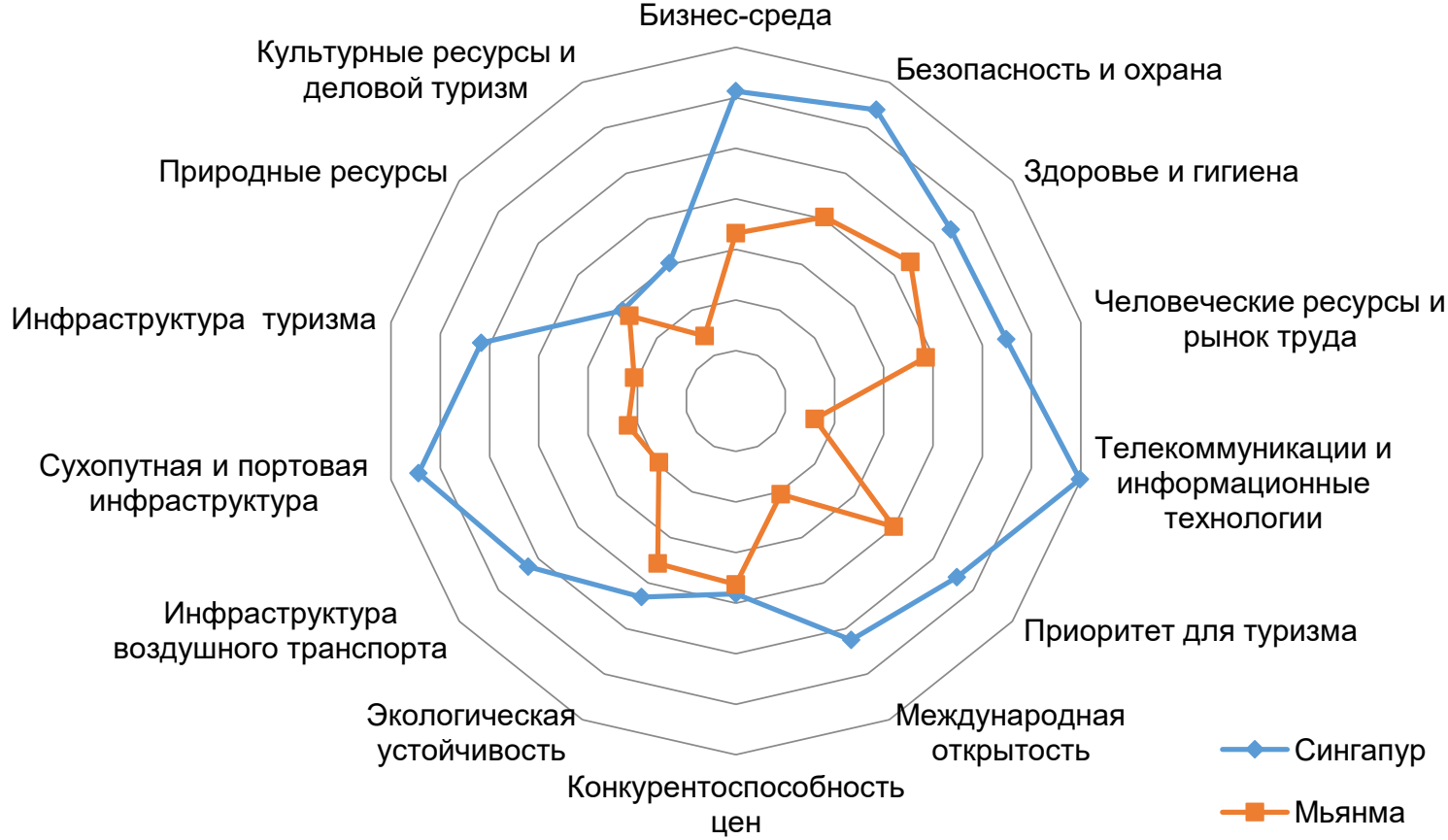

Рисунок 4 - Сравнительная оценка элементов ИкТП:

a - для двух групп стран в регионе, б - для Сингапура и Мьянмы 
Большая разница в положении государств замедляет темпы развития ГТБ всего АЕС, снижает престиж региона. Трудности каждого члена становятся общей проблемой всего экономического объединения. При сохранении подобного положения совместные стратегии, планы и соглашения по развитию туристической сферы не получат возможности эффективной реализации, интересы каждого участника не будут обеспечены, что может привести к возникновению неустранимых противоречий и разобщению AEC.

Кроме того, между членами AEC существуют различия в регулировании экономики, оказывающие немалое влияние на планирование в области ГТБ. Страны АСЕАН отличаются друг от друга экономическими институтами, качеством демократии, уровнем распространения коррупции, степенью экономической свободы, средой ведения бизнеса и т. д. (таблица 1).

Таблица 1 - Различия между государствами АСЕАН

\begin{tabular}{|l|l|c|c|}
\hline \multicolumn{1}{|c}{$\begin{array}{c}\text { ССрана } \\
\text { АСЕАН }\end{array}$} & \multicolumn{1}{|c|}{ Экономический институт [4] } & $\begin{array}{c}\text { Рейтинг экономической } \\
\text { свободы (100 - самая } \\
\text { свободная) [5] }\end{array}$ & $\begin{array}{c}\text { Индекс восприятия } \\
\text { коррупции (чем } \\
\text { выше, тем лучше) [6] }\end{array}$ \\
\hline Бруней & $\begin{array}{l}\text { Рыночная экономика, направленная на } \\
\text { экспорт }\end{array}$ & 68,9 & - \\
\hline Вьетнам & Переходная экономика & 51,7 & 38 \\
\hline Филиппины & $\begin{array}{l}\text { Рыночная экономика, направленная на } \\
\text { экспорт }\end{array}$ & 62,2 & 34 \\
\hline Индонезия & То же & 58,1 & 21 \\
\hline Камбоджа & Переходная экономика & 57,5 & 52 \\
\hline Лаос & То же & 51,4 & 21 \\
\hline Малайзия & $\begin{array}{l}\text { Рыночная экономика, направленная на } \\
\text { экспорт }\end{array}$ & 70,8 & 84 \\
\hline Мьянма & Центрально-плановая экономика & 46,9 & 52 \\
\hline Сингапур & $\begin{array}{l}\text { Рыночная экономика, направленная на } \\
\text { экспорт }\end{array}$ & 89,4 & \\
\hline Таиланд & То же & 61,4 & \\
\hline
\end{tabular}

Эти различия затрудняют достижение поставленных целей при развитии ГТБ членами AEC. Эти различия затрудняют достижение поставленных целей при развитии ГТБ членами АЕС. Страны с высоким уровнем экономической свободы и рыночной экономикой, направленной на экспорт, реализуют разумную политику, которая позволяет расширять участие государственного и частного секторов во всех сферах, особенно в областях создания инфраструктуры, образования, медицины, оказания услуг и т. д., повышать конкуренцию на внутреннем рынке, увеличивать конкурентоспособность предпринимателей в процессе интеграции. Поэтому в ГТБ, как и в других коммерческих сегментах, бизнес всегда своевременно реагирует на изменяющуюся конъюнктуру, быстро приспосабливается к новым условиям, активно ищет методы решения проблем и непрерывно обновляется и совершенствуется.

Страны с переходной экономикой, такие как Вьетнам, Лаос и Камбоджа, стараются перейти к рыночной экономике от плановой, однако пережитки этого строя не могут полностью и одномоментно исчезнуть. Менеджмент большинства государственных производителей и поставщиков гостиничных и туристических услуг (ГТУ) неэффективен. Даже поддержка со стороны власти не может обеспечить достаточный уровень их конкурентоспособности. Кроме того, коррупция снижает продуктивность управления и перераспределения ресурсов как в сфере туризма, так и в других областях. На непрозрачном рынке частные предприниматели либо с трудом ведут бизнес, либо воспринимают негативные фракторы как стандартные условия существования и процветания дела. Следовательно, реализация общей политики регулирования и развития туризма всего AEC станет возможной только тогда, когда будут изжиты негативные тенденции, экономика стран - участниц АСЕАН начнет воспринимать этику и культуру предпринимательства передовых государств, правительство и бизнес станут активно противостоять коррупции.

Общий рынок АCEAH в сфере туризма должен иметь единые политику развития, бизнессреду, нормы, правила, ценности для обеспечения эффективной координации производителей, поставщиков ГТУ в регионе; устранять конфликты интересов сторон из-за разницы в экономическом устройстве, уровнях экономической свободы и т. д. Однако преодоление различий - непростая задача, которую нельзя решить в короткие сроки.

2. После создания АEC принято соглашение о свободе передвижения квалифицированной рабочей силы. С одной стороны, данный договор между участниками объединения может усилить обмен интеллектуальными ресурсами, создать пространство для ознакомления с новыми знаниями, навыками и современными технологиями в сфере туризма. С другой стороны, этот документ способен спровоцировать «утечку мозгов» из стран-членов с развивающимся туризмом 
в Сингапур, Малайзию и Таиланд, обладающие благоприятными условиями для жизни и построения карьеры. Это становится проблемой для Лаоса, Вьетнама, Мьянмы и Камбоджи, особенно когда дефицит квалифицированных кадров в туризме становится все более масштабным.

В АСЕАН соглашение о признании сертификатов и дипломов о профессиональной квалификации работников туристической отрасли внутри нового экономического пространства может повысить качество трудовых ресурсов, но это не значит, что предлагаемые условия жизни, получения образования и карьерного роста в развивающихся странах-членах способны удержать талантливых сотрудников. Чтобы создать приемлемую систему подготовки высококвалифицированных кадров в данных государствах, необходимы реформы образования, подразумевающие значительные временные, интеллектуальные и финансовые затраты, а не просто договор о взаимном признании дипломов.

В связи с этим проблема «утечки мозгов» оказывает большое влияние на туристический бизнес в развивающихся странах. Исходя из этого, ГТБ во всем регионе развивается несоразмерно, различия в уровнях экономики углубляются и разобщение АСЕАН становится неизбежным.

3. Свобода передвижения товаров и услуг, отмена визового режима для граждан государств - членов АСЕАН и упрощение визового режима для граждан стран вне региона заставляют участников АЕС противостоять трудностям в сфрере поддержания социально-экономической безопасности, которая оказывает значительное влияние на развитие ГТБ. Можно перечислить следующие проблемы в данной области:

- Контрабанда товаров, особенно низкокачественных и поддельных (продовольственных и содержащих опасные химические вещества). Эти товары производятся в одной или нескольких странах - членах АCEAН, потом перевозятся в другие государства, отмечается также их приток из Китая в AEC. Распространение данных небезопасных товаров на рынке АCEAН не только угрожает здоровью населения и туристов в регионе, но и вызывает сумбур на товарном рынке, снижает доверие потребителей и ухудшает имидж АСЕАН в глазах гостей.

- Развитие секс-услуг. Отмена визового режима для граждан государств - членов АCEAH обусловила организацию данного нелегального рынка. Женщины, занимающиеся проституцией, могут свободно ездить в Сингапур, Малайзию и Таиланд. В Таиланде секс-туризм находится под запретом, но на практике широко распространен и привлекает немалое количество туристов. Государство и местные органы власти бессильны в управлении услугами, которые публично продаются и покупаются под защитой мафии. Следствием этого являются повышение числа случаев заражения ВИЧ, сексуального насилия над детьми, а также общее негативное влияние на традиционную культуру и общество.

- Незаконные изготовление, перевозка, приобретение, хранение и сбыт наркотических и психотропных средств. Свобода передвижения товаров и отмена визового режима также создают благоприятные условия для осуществления данных преступных действий, оказывающих влияние на развитие туризма. Они не только угрожают фризическому и нравственному здоровью общества, снижают производительность труда, но и сопровождаются рядом других противоправных действий, таких как грабеж, мошенничество, нарушение общественного порядка и т. д. Все это приводит к нестабильности социума, угрожает безопасности населения и туристов, а также является препятствием для развития ГТБ.

- Усиление террористической активности в регионе. Объединение стран - членов ACEAН, формирование общего рынка, свобода передвижения между государствами-участниками служат благоприятными условиями для деятельности террористов. Основная цель террористических организаций, действующих в регионе, - создание панисламистского государства на территориях современных Индонезии, Малайзии и части Филиппин [7, с. 235]. В Индонезии возникли небольшие исламистские группировки, ведущие террористическую деятельность. Индонезийские военные, участвовавшие в борьбе на Ближнем Востоке, могут возвращаться в страну, устанавливать связи с террористическими группами как в Индонезии, так и в АСЕАН. На Филиппинах исламский освободительный фронт моро, являющийся частью запрещенной в РФ «Аль-Каиды», может предпринимать неожиданные атаки, устанавливать отношения с ИГИЛ (организацией, также запрещенной в России) в Ираке и Сирии [8]. В Малайзии четыре террористические исламские группировки претендовали на некоторые области в Юго-Восточной Азии. Терроризм представляет большую угрозу для всех участников АСЕАН в процессе стабилизации экономики, политики, общества и, безусловно, развития ГТБ.

4. В отличие от государств Европейского союза 10 государств - членов АСЕАН никогда не откажутся от суверенитета и не будут создавать наднациональные органы. Европейская интеграция ориентирована на размывание государственных границ, а азиатская - на их укрепление и тщательную взаимную «притирку» с тем, чтобы исключить в будущем проблемы, способные 
ослабить ту или иную страну [9, с. 30, 31]. Следовательно, вопросы суверенности и территориальные споры в Южно-Китайском море могут стать барьером для сотрудничества и развития как ГТБ, так других сфер. Противоречия и конфликты между участниками объединения обусловливают нестабильность в экономике, политике и социуме региона.

Прежде всего необходимо упомянуть следующие конфликты между странами - членами ACEAH: споры Таиланда и Камбоджи о храме Preah Vihear, территориальные проблемы между Малайзией и Филиппинами по поводу участков штата Sabah и моря Sulu, между Индонезией и Малайзией вокруг островов Ligitan и Sipadan и другие столкновения интересов Сингапура и Малайзии, Камбоджи и Вьетнама, Таиланда и Мьянмы. Кроме того, существуют территориальные споры между государствами - участниками АCEАН и Китаем в Южно-Китайском море. КНР, представляющая одну из крупных экономик мира, граничит с Вьетнамом, Мьянмой, Лаосом и является потенциальным партнером AEC в сорере туризма и многих других областях.

Китай вкладывает огромные средства в построение системы железнодорожного транспорта «Сингапур - Куньмин». Специалисты считают ее «стратегической ловушкой» для стран - членов АСЕАН. Реализация данного проекта позволит КНР привязать АСЕАН к провинции Юньнань и Гуанси-Чжуанскому автономному району. Следовательно, развитие туризма государств АСЕАН, неотъемлемого от общей экономики региона, также зависит от отношений с Китаем.

Противоречия и территориальные споры между АСЕАН и КНР не только вызывают трудности при интеграции и развитии региональной экономики, в том числе ГТБ, но и приводят к социально-экономической и политической нестабильности. Особенно когда Китай ставит АСЕАН в «неудобное» положение, которое заставляет членов объединения использовать силу для охраны суверенитета государств. Процесс совершенствования системы ГТБ АЕС и в будущем не сможет избежать трудностей, возникающих из-за социально-экономических и политических проблем как одного участника АCEAН, так и всего региона.

5. При сотрудничестве страны - члены АCEAН сталкиваются с вопросами устойчивого развития туристической отрасли. Речь идет о расширении так называемых «массового туризма» (masstourism) и «мегамассового туризма» (mega-masstourism) для получения прибыли без учета ценностей и традиций местных жителей и воздействия на окружающую среду.

В процессе интеграции размывание традиционного уклада жизни и восприятие новых культурных потоков неизбежны. Для стран АСЕАН актуальна проблема утраты данных ценностей, представляющих собой бесценный культурный потенциал региона. Поэтому помимо обмена между участниками АСЕАН навыками и знаниями для совместного сохранения традиций органы власти государств должны предлагать стратегии и методики сбережения разнообразия культур юго-восточно-азиатских стран, развития собственного колорита и передачи традиций будущим поколениям.

Проблема расширения индустрии туризма интересует многих специалистов. Туризм, с одной стороны, приносит гигантскую прибыль, а с другой - воздействует (порой негативно) на окружающую среду, культуру и общество [10]. Погоня за прибылью и увеличением ВВП без внимания к экологии, культурным ценностям и социальным трансформациям может привести к спаду в самой сфрере ГТУ [11]. Для АСЕАН это становится актуальным вопросом, особенно при возрастании туристических потоков и создании имиджа идеального места отдыха. Количество туристов в 2013 г. составило 102,2 млн человек, в 2014 - 105, по прогнозам в 2025 г. это число может возрасти до 152 млн [12]. Однако в развивающихся странах - участницах АСЕАН дефицит финансовых средств, неразвитая инфраструктура, неквалифицированное управление усугубляют указанные негативные последствия массового туризма и неверной правительственной политики.

Неконтролируемый приток туристов вынуждает руководство стран прибегать к серьезным мерам для исправления ситуации. Правительство Таиланда закрыло остров Ко Тачай в области Phangnga и три острова Ко Кхай Нок, Ко Кхай Нуи и Ко Кхай Най на неопределенный срок из-за перегрузки и загрязнения окружающей среды. Малайзия также закрыла доступ на 12 пляжей и акваторий. Деревня Ванг Вьенг считается одним из популярных мест отдыха на севере Лаоса. Там был построен ряд баров, привлекавших молодежь наркотиками, алкоголем, находящимися в свободном доступе, и другими опасными развлечениями, что приводило к десяткам смертей только в течение года [13]. Местные дети в горах Сапа на севере Вьетнама пропускают занятия для того, чтобы просить деньги у туристов. В конце 2016 г. здесь построены 250 новых отелей. Число туристов в 2016 г. достигло 1 млн - в 3 раза больше, чем в предыдущем году, и в 15 раз чем в 2002 г. Такой значительный приток не может не влиять на экологию и традиции коренного населения. Первыми нежелательными последствиями послужили загрязнение природного горячего источника и снижение доходов местных жителей из-за увеличения количества отелей и отказа туристов от homestay-услуг. Поэтому в процессе сотрудничества необходимо не только преследовать цель получения выгоды, но и искать пути устойчивого развития сферы туризма, позволяющие уменьшать негативные последствия. 
Таким образом, мы обозначили некоторые проблемные вопросы в сфере ГТБ АЕС, требующие консолидации и координации усилий всех участников объединения. В том числе существуют проблемы, которые имеют долгосрочное влияние на развитие рассматриваемой сферы, такие как территориальные споры, мегамассовый туризм, «утечка мозгов» и увеличение террористической активности. Наблюдаются также трудности, в реальном времени воздействующие на ГТБ стран - членов АСЕАН: разница уровней развития экономики, политики регулирования, коррупции, безопасности региона. Для достижения успеха в индустрии туризма государства участники AEC должны противостоять разнообразным препятствиям и воспринимать их в качестве движущей силы, позволяющей совершенствовать гостиничный и туристический бизнес.

\section{Ссылки:}

1. Рейтинг стран мира по уровню валового внутреннего продукта [Электронный ресурс]. URL: http://gtmarket.ru/ratings/rating-countries-gdp (дата обращения: 10.02.2017) ; Рейтинг стран мира по уровню развития информационно-коммуникационных технологий [Электронный ресурc]. URL: http://gtmarket.ru/ratings/ict-developmentindex/ict-development-index-info (дата обращения: 10.02.2017) ; Рейтинг стран мира по уровню валового национального дохода на душу населения [Электронный ресурc]. URL: http://gtmarket.ru/ratings/rating-countries-gni (дата обращения: 10.02.2017).

2. Рейтинг стран мира по уровню прямых иностранных инвестиций [Электронный ресурc]. URL: http://gtmarket.ru/research/foreign-direct-investment-index/info (дата обращения: 10.02.2017).

3. Рейтинг стран мира по уровню конкурентоспособности путешествий и туризма в 2015 г. [Электронный ресурс]. URL: http://gtmarket.ru/news/2015/05/07/7152 (дата обращения: 10.02.2017)

4. Nguyễn Xuân Thắng. Chênh lệch phát triển và an ninh kinh tế ở ASEAN. Hà Nối, 2006. 227 tr.

5. Рейтинг стран мира по уровню экономической свободы [Электронный ресурc]. URL: http://gtmarket.ru/ratings/index-ofeconomic-freedom/index-of-economic-freedom-info (дата обращения: 10.02.2017).

6. Рейтинг стран мира по уровню восприятия коррупции [Электронный ресурc]. URL: http://gtmarket.ru/ratings/corruptionperceptions-index/info (дата обращения: 10.02.2017).

7. Малетин Н.П. АСЕАН. Четыре десятилетия развития : монография. М., 2007. 321 с

8. Vũ Thảo. Báo động nguy cơ khủng bố Hồi giáo tại Đông Nam Á [Электронный ресypc]. URL: http://vnexpress.net/tin-tuc/thegioi/phan-tich/bao-dong-nguy-co-khung-bo-hoi-giao-tai-dong-nam-a-3074429.html (дата обращения: 10.02.2017)

9. Васильев Л.Е. АСЕАН в начале XXI в. Актуальные проблемы и перспективы. М., 2010. 368 с.

10. Becker E. The exploding business of travel and tourism. N. Y., 2013. $448 p$

11. Nguyễn Xuân Thắng. Op. cit.

12. ASEAN khởi động kế hoạch thúc đẩy du lịch 2016-2025 [Электронный pecypc]. URL: http://www.sggp.org.vn/thegioi/2016/1/410128 (дата обращения: 10.02.2017).

13. Đặng Hoàng Giang. Bức xúc không làm ta vô can. Hà Nội, 2015. 221 tr.

\section{References:}

ASEAN khởi động kế hoạch thúc đẩy du lịch 2016-2025 2017, viewed 10 February 2017, <http://www.sggp.org.vn/thegioi/2016/1/410128>, (in Vietnamese).

Becker, E 2013, The exploding business of travel and tourism, New York, $448 \mathrm{p}$.

Đăng Hoàng Giang, 2015, Bức xúc không làm ta vô can, Hà Nội, 221 tr., (in Vietnamese).

Maletin, NP 2007, ASEAN. Four decades of development, monograph, Moscow, 321 p., (in Russian).

Nguyễn Xuân Thắng, 2006, Chênh lệch phát triển và an ninh kinh tể ở ASEAN, Hà Nội, 227 tr., (in Vietnamese).

Thảo, Vũ 2017, Báo động nguy cơ khủng bố Hồi giáo tại Đông Nam Á, viewed 10 February 2017, <http://vnexpress.net/tintuc/the-gioi/phan-tich/bao-dong-nguy-co-khung-bo-hoi-giao-tai-dong-nam-a-3074429.html>, (in Vietnamese).

Vasiliev, LE 2010, ASEAN at the beginning of XXI century. Topical problems and prospects, Moscow, 368 p., (in Russian). 